Retraction

\title{
Retracted: The Effects of Positive or Neutral Communication during Acupuncture for Relaxing Effects: A Sham-Controlled Randomized Trial
}

\author{
Evidence-Based Complementary and Alternative Medicine
}

Received 24 August 2016; Accepted 24 August 2016

Copyright (C) 2016 Evidence-Based Complementary and Alternative Medicine. This is an open access article distributed under the Creative Commons Attribution License, which permits unrestricted use, distribution, and reproduction in any medium, provided the original work is properly cited.

At the request of the authors, the article titled "The Effects of Positive or Neutral Communication during Acupuncture for Relaxing Effects: A Sham-Controlled Randomized Trial" [1] has been retracted. The ethical approval number given in the article and the proceedings related to the approval were incorrect.

\section{References}

[1] A. Rosén, M. Lekander, K. Jensen et al., "The effects of positive or neutral communication during acupuncture for relaxing effects: a sham-controlled randomized trial," Evidence-based Complementary and Alternative Medicine, vol. 2016, Article ID 3925878, 11 pages, 2016. 